\title{
PARTISIPASI MASYARAKAT DALAM MENGURANGI RISIKO KERUSAKAN SITU-SITU DI KECAMATAN CIMANGGIS, KOTA DEPOK
}

\section{COMMUNITY PARTICIPATION IN REDUCING THE RISK OF SMALL LAKES IN CIMANGGIS SUB DISTRICT, DEPOK CITY}

\author{
Tiffa Yuki Dewanti ${ }^{1}$ dan Heru Sri Naryanto ${ }^{2}$ \\ ${ }^{1}$ Magister IImu Geografi, FMIPA-UI, Depok \\ e-mail: tiffayuki94@gmail.com \\ ${ }^{2}$ Pusat Teknologi Reduksi Risiko Bencana, Kedeputian Teknologi Sumberdaya Alam, Badan \\ Pengkajian dan Penerapan Teknologi (BPPT), Gedung Geostech, Puspiptek Serpong, Kota \\ Tangerang Selatan \\ e-mail: heru.naryanto@bppt.go.id
}

\begin{abstract}
Depok City has a function as a water catchment in reducing flooding in Jakarta City and in Depok City itself, the existence of existing sites is very important to be maximized. At present there are only 21 small lakes in Depok City whose existence is still maintained. Lately the condition are decreasing both in terms of quality and quantity. There are 6 small lakes in Cimanggis subdistricts, namely: Situ Gadog, Situ Pedongkelan, Situ Rawa Kalong, Situ Tipar, Situ Jemblung, and Situ Rawa Gede, which as a whole have an area of 32.4 Ha. To maintain the sustainability of small lakes in the Cimanggis sub-district, damage risk reduction is urgently needed to sustain the function of these small lakes. There are 5 variables of community participation in damage risk reduction in Cimanggis sub-district. Five variables to measure the level of community participation are community participation in the form of thoughts, community participation in the form of property, community participation in the form of energy, community participation in the form of skills, and community participation in social forms.
\end{abstract}

Keywords: community participation, small lake, Cimanggis, damage risk reduction

\begin{abstract}
ABSTRAK
Kota Depok mempunyai fungsi sebagai resapan air dalam mengurangi banjir di DKI Jakarta maupun di Kota Depok sendiri, eksistensi situ-situ yang ada sangat penting untuk dimaksimalkan. Saat ini hanya ada 21 situ di Kota Depok yang eksistensinya masih terjaga. Kondisi situ setiap tahunnya menurun baik dari segi kualitas maupun kuantitas. Kecamatan Cimanggis terdapat 6 situ besar, yaitu: Situ Gadog, Situ Pedongkelan, Situ Rawa Kalong, Situ Tipar, Situ Jemblung, dan Situ Rawa Gede yang secara keseluruhan mempunyai luas 32,4 Ha. Untuk menjaga kelestarian situ di kecamatan Cimanggis, maka pengurangan risiko kerusakan situ sangat dibutuhkan untuk melindungai eksistensi situ tersebut secara berkelanjutan. Ada 5 variabel partisipasi masyarakat dalam pengurangan risiko kerusakan situ di Kecamatan Cimanggis. Lima variabel untuk mengukur tingkat partisipasi masyarakat tersebut adalah partisipasi masyarakat dalam bentuk buah pikiran, partisipasi masyarakat dalam bentuk harta benda, partisipasi masyarakat dalam bentuk tenaga, partisipasi masyarakat dalam bentuk keterampilan, dan partisipasi masyarakat dalam bentuk sosial.
\end{abstract}

Kata kunci: partisipasi masyarakat, situ, Cimanggis, pengurangan risiko kerusakan 


\section{PENDAHULUAN}

\subsection{Latar Belakang}

Kota Depok selain merupakan pusat pemerintahan yang berbatasan langsung dengan wilayah DKI Jakarta merupakan wilayah penyangga yang diarahkan menjadi kota pemukiman, kota pendidikan, pusat pelayanan perdagangan dan jasa, kota pariwisata dan sebagai kota resapan air. Fungsi sebagai daerah resapan sangat diharapkan untuk mengurangi banjir di DKI Jakarta maupun di Kota Depok sendiri.

Menurut Pemerintah Kota Depok (2012), saat ini hanya ada 21 situ di Kota Depok yang eksistensinya masih terjaga. Beberapa situ di Kota Depok telah menghilang pada saat perpindahan pemerintahan dari Kabupaten Bogor berpisah menjadi Kota Depok. Situ tersebut sudah tidak terawat hingga air situ mengering kemudian dimanfaatkan oleh warga menjadi pemukiman kumuh dan perladangan. Seluruh nama situ-situ yang sudah menghilang tetap tercantum dalam Perda RTRW Kota Depok karena merupakan aset yang dimiliki Kota Depok sehingga walaupun eksistesinya sudah tidak ada namun penamaan situ tidak akan dihilangkan.

Danau yang berukuran kecil disebut dengan nama situ, dan saat ini penggunaan nama situ sudah dibakukan menjadi bahasa nasional. Ukuran situ yang relatif kecil menyebabkan keberadaannya sangat terancam oleh tingginya laju sedimentasi. Situ yang lebih dangkal dampaknya akan sangat terlihat jika terjadi sedimentasi hingga lambat laun fungsi dan kondisi situ berubah menjadi sebidang lahan.

Kondisi situ-situ yang ada di Kota Depok masih memprihatinkan. Banyaknya penduduk yang datang dari luar daerah yang tidak memiliki tempat tinggal dan mendirikan bangunan di daerah sempadan situ menyebabkan menumpuknya sampah rumah tangga yang menjadi sumber utama pencemaran situ lalu terjadi pendangkalan dan pengkayaan mineral (eurtrofikasi) sehingga gulma air tumbuh subur. Karena banyak kondisi lingkungan situ yang rusak, dalam arti banyak lingkungan hidup yang tidak seimbang keadaanya sehingga kurang ada manfaatnya lagi bagi kehidupan manusia padahal situ memiliki banyak manfaat.

Situ adalah wadah genangan air di atas permukaan tanah yang terbentuk secara alami maupun buatan, sumber airnya berasal dari mata air, air hujan, dan/atau limpasan air permukaan. Maka dapat ditarik kesimpulan bahwa situ adalah suatu wilayah berupa cekungan air yang berasal dari limpasan air di sekitarnya (Puspita et al, 2005). Dari sudut ekologi, situ merupakan ekosistem yang terdiri dari unsur air, kehidupan akuatik, dan daratan yang dipengaruhi tinggi rendahnya muka air, sehingga kehadiran waduk akan mempengaruhi iklim mikro dan keseimbangan ekosistem di sekitarnya. Sedangkan ditinjau dari sudut tata air situ berperan sebagai reservoir yang dapat dimanfaatkan airnya untuk keperluan sistem irigasi dan perikanan, sebagai sumber air baku, sebagai tangkapan air untuk pengendali banjir, suplai air tanah dan pariwisata (Naryanto, 2011, Naryanto, 2013).

Mengingat pentingnya fungsi situ sebagai penyangga kehidupan, maka situ harus dilindungi dan dijaga kelestariannya, ditingkatkan fungsi dan manfaatnya, dan dikendalikan daya rusaknya terhadap lingkungan. Sehubungan dengan hal itu maka perencanaan pengelolaannya ditujukan pada upaya pengurangan risiko kerusakan dan perlindungan, sehingga pemanfaatannya dapat berkelanjutan tanpa mengubah fungsi situ (Naryanto, 2011). Dalam penerapannya, pengurangan risiko kerusakan situ membutuhkan peran semua pihak baik secara individu, masyarakat, sampai pada pemerintah daerah maupun pusat.

Masyarakat harus berpartisipasi dalam pemberdayaan mereka sendiri karena tujuan, cara dan hasil harus dirumuskan mereka sendiri. Tingkat kesadaran masyarakat merupakan kunci dalam pemberdayaan, karena pengetahuan dapat memobilisasi tindakan bagi perubahan pemberdayaan juga melibatkan akses terhadap sumber-sumber dan kemampuan untuk menggunakan sumbersumber tersebut secara efektif (Suharto, 2004). Masyarakat dan pemerintah setempat hendaknya belajar dari kesalahan atas situsitu yang telah hilang sehingga situ yang belum rusak hendaknya tetap dipelihara, diawasi, dijaga kelestariannya dan dilindungi agar situ tidak rusak dan hilang karena situsitu tersebut merupakan aset yang berharga bagi Kota Depok.

\subsection{Maksud dan Tujuan}

Maksud dari penelitian ini adalah untuk mengurangi risiko kerusakan situ-situ di Kecamatan Cimanggis, Kota Depok, sehingga 
bisa memaksimalkan peran dari situ-situ tersebut. Tujuannya adalah untuk menganalisis seberapa besar tingkat partisipasi masyarakat terhadap pengurangan risiko kerusakan situ-situ dalam bentuk buah pikiran, harta benda, tenaga, keterampilan, dan sosial sehingga dapat diketahui besarnya tingkat partisipasi masyarakat terhadap upaya pengurangan risiko terhadap kerusakan situsitu serta untuk mengetahui persepsi masyarakat dengan menggali apa saja yang menjadi harapan (expectation) masyarakat yang berada di kawasan sekitar situ-situ tersebut.

\section{METODOLOGI}

\subsection{Waktu dan Tempat Penelitian}

Penelitian ini dilakukan dalam jangka waktu 2016. Metode penelitian yang digunakan adalah studi kasus. Menurut Nazir (1983) dan (Akhirianto \& Naryanto, 2016), penelitian studi kasus adalah penelitian tentang status subjek penelitian yang berkenan dengan suatu fase spesifik atau khas dari keseluruhan personalitas. Subjek penelitian dapat saja individu, kelompok, lembaga, maupun masyarakat. Pemilihan tempat penelitian dilakukan secara purposive maka dipilihlah Kecamatan Cimanggis, Kota Depok.

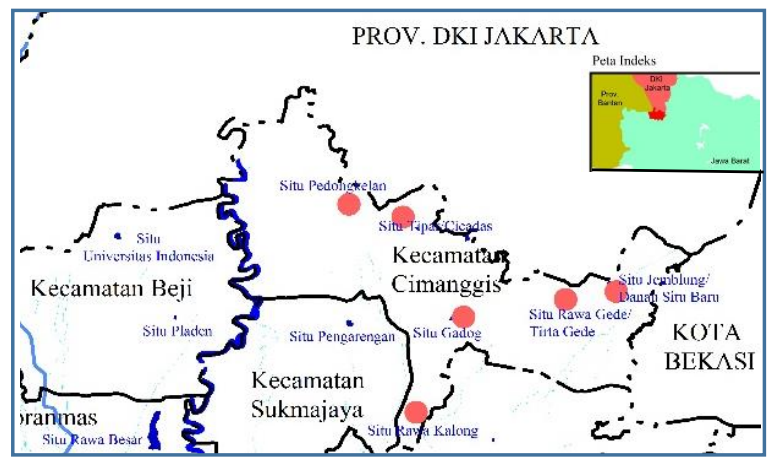

Gambar 1. Sebaran Situ-Situ di Kecamatan Cimanggis

\subsection{Pengambilan Data}

Berdasarkan penjelasan di atas maka teknik sampling yang diambil adalah teknik nonprobability sampling artinya teknik pengambilan sampel yang tidak memberi peluang/kesempatan sama bagi setiap unsur atau anggota populasi untuk dipilih menjadi sampel. Beberapa jenis sampling yang ada dalam nonprobability sampling, peneliti memilih jenis sampling purposive. Menurut Sugiyono (2013), bahwa sampling purposive adalah teknik penentuan sampel dengan pertimbangan tertentu. Dengan pertimbangan tertentu maka peneliti memilih sampel di Kecamatan Cimanggis dengan alasan memiliki total luas situ terbesar pada suatu kecamatan dan termasuk salah satu wilayah yang mengalami kerusakan situ sangat besar. Mengingat pentingnya fungsi situ sebagai penyangga kehidupan bagi masyarakat, apabila situ tersebut mengalami kerusakan seperti tercemar atau banjir meluap maka yang akan terkena dampaknya pertama adalah masyarakat di sekitar situ atau masyarakat yang terdekat dari situ. Apabila semakin banyak jumlah situ atau total luas situ semakin besar pada suatu wilayah maka akan lebih berdampak pada masyarakatnya (Dewanti, 2016).

Data yang digunakan pada penelitian ini adalah data primer dan data sekunder. Metode yang digunakan untuk mendapatkan data primer menggunakan kuesioner yang ditujukan kepada responden yaitu masyarakat Kecamatan Cimanggis, Kota Depok. Pengambilan sampel sumber data dilakukan secara purposive dan snowball. Metode sampling purposive yaitu pengambilan sampel berdasarkan "penilaian" (judgement) peneliti mengenai siapa saja yang pantas (memenuhi persyaratan) untuk dijadikan sampel. Sampling purposive dapat diartikan juga teknik pengambilan sampel sumber data dengan pertimbangan tertentu. Sedangkan snowball sampling merupakan metode pengambilan sampel dengan secara berantai (multilevel) (Sugiyono, 2013; Akhirianto \& Naryanto, 2016).

\subsection{Teknik Pengumpulan Data}

Berdasarkan sifat permasalahan dalam penelitian ini menggunakan metode deskriptif yaitu sebuah metode yang bertujuan untuk menemukan sebuah gambaran dalam suatu kelompok manusia, suatu obyek, suatu keadaan atau kondisi. Tujuan dari penelitian deskriptif ini untuk membuat deskripsi atau gambaran secara sistematis pada penggungkapan fakta-fakta dan keadaan yang terjadi di wilayah penelitian mengenai pendapat, tanggapan, ide, ataupun gagasan yang dimiliki masyarakat dalam upaya pengurangan risiko kerusakan situ-situ di Kecamatan Cimanggis. Dalam penelitian ini terdiri dari lima variabel bebas $(X)$ dan satu variabel terikat $(\mathrm{Y})$. 
Dalam penelitian ini teknik pengumpulan data yang digunakan untuk mencari data yang relevan untuk kemudian dianalisis dengan cara observasi ke lokasi penelitian yaitu situsitu di Kecamatan Cimanggis, kemudian peneliti membagikan instrumen kuesioner kepada warga yang berisi pertanyaan seputar partisipasi masyarakat dalam upaya pengurangan risiko kerusakan situ. Selain itu peneliti juga akan melakukan wawancara kepada petugas RT/RW, kelompok kerja (pokja) situ maupun warga setempat untuk menunjang data serta melakukan dokumentasi terhadap lokasi penelitian. Dengan dilakukannya teknik-teknik pengumpulan data tersebut maka peneliti dapat mengolahnya untuk mendapatkan hasil yang diinginkan. Berikut penjabaran dari teknik pengumpulan data:

- Observasi Lapangan

Pengumpulan data dengan melakukan pengamatan dan pencatatan secara sistematik terhadap gejala atau fenomena yang ada pada obyek penelitian.

- Wawancara

Untuk mendapatkan informasi yang digali dari sumber data langsung melalui percakapan atau tanya jawab. Tujuan dari wawancara jenis ini adalah untuk menemukan permasalahan secara lebih terbuka, dimana pihak yang diajak wawancara diminta pendapat, dan ideidenya (Satori dan Komariah, 2014).

- Kuesioner

Dalam penelitian ini menggunakan angket berstruktur untuk memperoleh data yang bersifat faktual dari responden dengan cara memberikan instrumen kuesioner yang berisi beberapa pertanyaan yang harus diisi oleh responden, untuk mengetahui seberapa besar tingkat hubungan bentuk partisipasi masyarakat dalam upaya pengurangan risiko kerusakan situ-situ di Kecamatan Cimanggis, Kota Depok.

- Pengumpul data karena instrumen tersebut sudah baik. Uji validitas dan reliabilitas dilakukan menggunakan program Statistical Product and Service Solutions (SPSS 24) (Sugiyono, 2010; Arikunto, 2006).

- Statistik deskriptif menggunakan program SPSS 24, untuk menggambarkan kapasitas masyarakat (responden) terkait pengurangan risiko kerusakan situ. Menurut Sugiyono (2012, statistik deskriptif merupakan statistik yang berfungsi untuk mendiskripsikan atau memberi gambaran terhadap obyek yang diteliti melalui data sampel atau populasi sebagaimana adanya, tanpa melakukan analisis dan mebuat kesimpulan yang berlaku untuk umum.

- Skala likert untuk menganalisis tingkat persepsi terkait harapan (expectation) responden. Skala likert merupakan sebuah skala yang menggunakan ukuran ordinal untuk mengukur sikap masyarakat yang telah dikembangkan sejak tahun 1932 (Nazir, 1983; Akhirianto \& Naryanto, 2016).

\subsection{Analisis Data}

Analisis data yang digunakan dalam penelitian ini adalah sebagai berikut:

- Uji validitas dan reliabilitas kuesioner yang digunakan dalam penelitian. Uji validitas dilakukan untuk memastikan seberapa baik suatu instrumen digunakan untuk mengukur konsep yang seharusnya diukur. Sedangkan reliabilitas menunjuk pada suatu pengertian bahwa sesuatu instrumen cukup dapat dipercaya untuk digunakan sebagai alat.

\section{HASIL DAN PEMBAHASAN}

\subsection{Kondisi Lingkungan Situ}

Jumlah penduduk di Kecamatan Cimanggis menurut data BPS Kota Depok (2015) sebesar 283.025 jiwa dengan komposisi penduduk laki-laki 143.260 jiwa dan perempuan 139.765 jiwa. Kecamatan Cimanggis merupakan kecamatan dengan jumlah penduduk tertinggi di Kota Depok dengan luas area sebesar 21,220 $\mathrm{km}^{2}$. Kecamatan Cimanggis berada di wilayah bagian utara Kota Depok yang pada umumnya memiliki topografi berupa dataran rendah dibandingkan dengan wilayah Depok bagian selatan dengan kemiringan lereng $2-15 \%$ serta memiliki ketinggian \pm 115 mdpl. Kecamatan Cimanggis merupakan salah satu kecamatan yang sering mengalami banjir setiap tahunnya didukung dengan kondisi geografis Kota Depok yang dialiri oleh sungai-sungai besar yaitu Sungai Ciliwung dan Sungai Cisadane yang termasuk kedalam dua Satuan Wilayah Sungai besar. Penggunaan lahan di Kecamatan Cimanggis sangat beragam didominasi oleh lahan bukan sawah yaitu lahan bangunan, pemukiman, jalan, danau, sungai, dan lain-lain.

Menurut RTRW tahun 2012 - 2032 yang dikeluarkan oleh Pemerintah Kota Depok (2012), Kecamatan Cimanggis memiliki 6 situ 
dengan total luas situ keseluruhan sebesar $32,4 \mathrm{Ha}$ dengan kedalaman situ bervariasi antara $1-5$ meter. Mayoritas situ memiliki kualitas air situ yang buruk akibat pencemaran. Permasalahan situ tidak hanya sekedar penurunan kualitas air tetapi kawasan situ juga mengalami kerusakan situ. Adapun situ-situ di Kecamatan Cimanggis adalah Situ Gadog, Situ Pedongkelan, Situ Rawa Kalong, Situ Tipar, Situ Jemblung (Danau Situ Baru), dan Situ Rawa Gede (Tirta Gede) (Tabel 1).
Tabel 1. Luas Situ-Situ di Kecamatan Cimanggis

\begin{tabular}{c|l|c}
\hline No. & \multicolumn{1}{|c}{ Nama Situ } & Luas (Ha) \\
\hline 1. & Situ Gadog & 1,3 \\
\hline 2. & Situ Pedongkelan & 6,25 \\
\hline 3. & Situ Rawa Kalong & 8,25 \\
\hline 4. & Situ Tipar & 8 \\
\hline 5. & $\begin{array}{l}\text { Situ Jemblung } \\
\text { (Danau Situ Baru) }\end{array}$ & 7,2 \\
\hline 6. & $\begin{array}{l}\text { Situ Rawa Gede } \\
\text { (Tirta Gede) }\end{array}$ & 1,4 \\
\hline & TOTAL LUAS SITU & 32,4 \\
\hline
\end{tabular}

Tabel 2. Kondisi Lingkungan Situ-Situ di Kecamatan Cimanggis

\begin{tabular}{|c|c|c|c|c|c|c|}
\hline No. & Nama Situ & Kedalaman & Sumber Air & Lingkungan & Pemanfaatan & Akses Jalan \\
\hline 1. & Situ Gadog & $\pm 1 m$ & $\begin{array}{l}\text { Situ Tertutup } \\
\text { - Input: Mata air } \\
\text { \& Limbah pasar } \\
\text { - Output: Kali }\end{array}$ & $\begin{array}{l}\text { - Situ Kotor } \\
\text { - Tidak ada } \\
\text { pohon }\end{array}$ & - Tadah hujan & $\begin{array}{l}\text { Di pinggir jalan } \\
\text { raya, masuk jalan } \\
\text { setapak }\end{array}$ \\
\hline 2. & $\begin{array}{l}\text { Situ } \\
\text { Pedongkelan }\end{array}$ & $\pm 4 m$ & $\begin{array}{l}\text { Situ Terbuka } \\
\text { - Input: Mata air } \\
\text { \& Sungai } \\
\text { Ciliwung } \\
\text { - Output: Kali } \\
\end{array}$ & $\begin{array}{l}\text { - Situ Kotor } \\
\text { - Pohon jarang- } \\
\text { jarang }\end{array}$ & $\begin{array}{l}\text { - Tadah hujan } \\
\text { - Pariwisata }\end{array}$ & $\begin{array}{l}\text { Jalan raya aspal, } \\
\text { parkir mobildan } \\
\text { motor }\end{array}$ \\
\hline 3. & $\begin{array}{l}\text { Situ Rawa } \\
\text { Kalong }\end{array}$ & $\pm 3 m$ & $\begin{array}{l}\text { Situ Tertutup } \\
\text { - Input: Mata air } \\
\text { - Output: Kali }\end{array}$ & $\begin{array}{l}\text { - Sempadan situ } \\
\text { menjadi TPS } \\
\text { - Pohon jarang- } \\
\text { jarang }\end{array}$ & $\begin{array}{l}\text { - Tadah hujan } \\
\text { - Tambak }\end{array}$ & $\begin{array}{l}\text { Jalan setapak dan } \\
\text { jalan perumahan }\end{array}$ \\
\hline 4. & Situ Tipar & $\pm 5 \mathrm{~m}$ & $\begin{array}{l}\text { Situ Tertutup } \\
\text { - Input: Mata air } \\
\text { \& Drainase } \\
\text { warga } \\
\text { - Output: Kali }\end{array}$ & $\begin{array}{l}\text { - Banyak eceng } \\
\text { gondok } \\
\text { - Banyak pohon }\end{array}$ & - Tadah hujan & $\begin{array}{l}\text { Setengah sisi } \\
\text { jalan raya, } \\
\text { sisanya Jalan } \\
\text { setapak kon blok }\end{array}$ \\
\hline 5. & $\begin{array}{l}\text { Situ } \\
\text { Jemblung / } \\
\text { Danau Situ } \\
\text { Baru }\end{array}$ & $\pm 5 \mathrm{~m}$ & $\begin{array}{l}\text { Situ Tertutup } \\
\text { - Input: Mata air } \\
\text { - Output: Kali }\end{array}$ & $\begin{array}{l}\text { - Sangat bersih } \\
\text { - Banyak pohon }\end{array}$ & $\begin{array}{l}\text { - Tadah hujan } \\
\text { - Pariwisata }\end{array}$ & Jalan raya aspal \\
\hline 6. & $\begin{array}{l}\text { Situ Rawa } \\
\text { Gede / Tirta } \\
\text { Gede }\end{array}$ & $\pm 1 \mathrm{~m}$ & $\begin{array}{l}\text { Situ Tertutup } \\
\text { - Input: Mata air } \\
\text { \& Drainase } \\
\text { warga } \\
\text { - Output: Kali }\end{array}$ & $\begin{array}{l}\text { - Tidak Terawat } \\
\text { - Banyak Pohon } \\
\text { - Lokasi } \\
\text { Shooting }\end{array}$ & - Tadah hujan & Jalan raya aspal \\
\hline
\end{tabular}


Sampel situ yang diteliti pada penelitian ini berjumlah 6 situ dengan kondisi relatif kritis. Hampir seluruh situ memiliki sumber dari mata air. Kondisi pohon-pohon di daerah sempadan situ masih terbilang jarang padahal seharusya daerah sempadan situ dapat dimanfaatkan sebagai daerah resapan air untuk menghindari banjir saat musim hujan tiba karena tidak ada tanah yang menampung air hujan, selain itu dapat terjadi kekeringan pada saat musim kemarau karena air hujan yang turun di musim hujan tidak tertampung di dalam tanah akibatnya air tanah hanya sedikit bahkan tidak ada. Hampir seluruh situ dikelilingi langsung oleh rumah warga yang hanya dibatasi oleh jalan setapak kon blok.

Situ Gadog dan Situ Tipar belum memiliki pariwisata namun memiliki potensi untuk dijadikan tempat wisata karena lokasinya strategis berada di pinggir jalan raya besar sehingga mudah untuk diakses oleh masyarakat. Jika berhasil dikembangkan area wisata permainan air dan rumah makan di sekitarnya maka Situ Gadog dan Situ Tipar dapat menjadi tujuan wisata bagi warga Kota Depok maupun warga luar Kota Depok.

Seluruh situ-situ di Kecamatan Cimanggis saat ini dalam kondisi kritis, beberapa situ yang kondisinya paling tidak aman diantaranya Situ Gadog dan Situ Rawa Kalong. Kondisi situ-situ tersebut cukup parah akibat pencemaran lingkungan oleh limbah pabrik dan limbah rumah tangga. Apabila dibiarkan maka situ-situ tersebut akan menghilang dalam jangka waktu yang cepat jika penanganannya tidak segera dilakukan. Situ Pedongkelan, Situ Tipar, Situ Jemblung dan Situ Rawa Gede dapat menghilang suatu waktu dalam jangka waktu yang masih relatif lama, mengingat dari segi luasannya yang masih cukup besar serta rata-rata memiliki saluran inlet dan outlet sehingga air masih dapat masuk dan keluar dengan baik.

\subsection{Pengambilan Sampel}

\subsubsection{Karakteristik Responden}

Karakteristik responden berdasarkan jenis kelamin pada lokasi sampel di dominasi oleh laki-laki. Hal tersebut disebabkan karena perempuan kurang mengerti dan jarang terlibat terlibat dengan kegiatan yang dilakukan di area sekitar situ sehingga seluruhnya diserahkan pada laki-laki. Perempuan di lokasi sampel masih memiliki pemikiran bahwa "perempuan hanya di dapur dan mengurus anak". Beberapa perempuan ada yang terlibat hanya karena suaminya ikut terlibat dalam upaya pengurangan risiko kerusakan situ.
Tabel 3. Karakteristik Responden Berdasarkan Jenis Kelamin

\begin{tabular}{c|c|c}
\hline Jenis Kelamin & Frekuensi & Prosentase \\
\hline Perempuan & 8 & 16,3 \\
\hline Laki-laki & 41 & 83,7 \\
\hline TOTAL & 49 & 100
\end{tabular}

Sumber: Hasil Analisis (2016)

Karakteristik responden berdasarkan usia pada lokasi sampel di dominasi oleh usia 5054 tahun. Hampir seluruh lokasi sampel berada di tempat yang sulit dijangkau atau jauh dari pusat kota sehingga mayoritas yang tinggal di lokasi tersebut adalah usia tua.

\subsection{Partisipasi Masyarakat Terhadap Pengurangan Risiko Kerusakan Situ \\ 3.3.1. Gambaran Umum Partisipasi Masyarakat Terhadap Pengurangan Risiko Kerusakan Situ \\ Partisipasi masyarakat yang diteliti pada} penelitian ini yaitu untuk menganalisis tingkat keterlibatan masyarakat terhadap pengurangan risiko kerusakan situ-situ di Kecamatan Cimanggis mengingat kondisi situ yang setiap tahunnya menurun baik dari segi kualitas maupun kuantitas. Terdapat 5 variabel untuk mengukur tingkat partisipasi masyarakat yaitu partisipasi masyarakat dalam bentuk buah pikiran, partisipasi masyarakat dalam bentuk harta benda, partisipasi masyarakat dalam bentuk tenaga, partisipasi masyarakat dalam bentuk keterampilan, dan partisipasi masyarakat dalam bentuk sosial. Untuk mendapatkan hasil yang lebih spesifik maka dari setiap variabel dipecah menjadi beberapa indikator.

Menganalisis tingkat partisipasi masyarakat dalam bentuk buah pikiran dapat dilakukan dengan cara memberikan ide/pendapat saat rapat berlangsung untuk melakukan kerja bakti dan membuat tanggul, merencanakan program pengurangan risiko kerusakan dengan cara merencanakan kerja bakti secara berkala misal dua minggu sekali atau melakukan penanaman pohon, mengembangkan program pengurangan risiko kerusakan dengan cara mengadakan kegiatan baru yang belum pernah dilakukan sebelumnya dalam rangka pengurangan risiko kerusakan situ. Menganalisis tingkat partisipasi masyarakat dalam bentuk harta benda dapat dilakukan dengan cara 
memberikan bantuan harta benda seperti bantuan uang, bantuan peralatan, bantuan makanan dan minuman saat kegiatan kerja bakti sedang berlangsung. Memberikan bantuan berupa informasi yaitu bantuan berupa media cetak seperti poster pamflet, dll. Menganalisis tingkat partisipasi masyarakat dalam bentuk tenaga dapat dilakukan dengan cara masyarakat mengikuti kegiatan pengurangan risiko kerusakan situ yang dilakukan di lingkungan situ sekitarnya seperti ikut serta dalam kerja bakti, ikut membuat tanggul, melakukan penanaman pohon, melakukan pengerukan, dan senantiasa turut memelihara kelestarian situ. Menganalisis tingkat partisipasi masyarakat dalam bentuk keterampilan dapat dilakukan dengan cara mengadakan pelatihan di lingkungan RT/RW setempat seperti memberikan contoh menanam pohon pada daerah sempadan situ beserta manfaatnya, memberikan pelatihan cara-cara mengurangi sedimentasi, memberikan pelatihan cara-cara meningkatkan jumlah air situ dengan cara menambahkan saluran input ke situ agar situ tidak mengalami kekeringan, memberikan contoh mengurangi pencemaran situ salah satunya dengan tidak membuang sampah ke situ. Menganalisis tingkat partisipasi masyarakat dalam bentuk sosial dapat dilakukan dengan cara mensosialisasikanya kepada masyarakat luas seperti menyebarkan informasi tentang adanya kegiatan pengurangan risiko kerusakan situ, mendiskusikan keberlanjutan kegiatan pengurangan risiko kerusakan situ untuk ke depannya, serta berkordinasi yang baik antar sesama warga saat bekerja, pada setiap akhir kegiatan perlu melakukan evaluasi/menilai setiap hasil pekerjaan agar kegiatan selanjutnya mendapatkan hasil yang lebih maksimal.

Berdasarkan dari data hasil responden di lapangan pembagian jumlah responden pada setiap situ, diketahui dari seluruh lokasi sampel yang berjumlah 6 situ, maka tidak ada situ yang mempunyai tingkat partisipasi masyarakat yang tinggi terhadap pengurangan risiko kerusakan situ, 5 situ memiliki tingkat partisipasi masyarakat yang sedang, sementara 1 situ lainnya yaitu Situ Gadog memiliki tingkat partisipasi masyarakat yang rendah (Tabel 4). Menurut Dewanti et al. (2016), Semakin tinggi tingkat partisipasi masyarakat terhadap pengurangan risiko kerusakan situ tinggi artinya pemerintah akan lebih mudah untuk mengembangkan situ tersebut agar lebih baik karena masyarakat sekitar situ memiliki kemauan tinggi dalam berkontribusi terhadap situ.

Tabel 4. Tingkat Partisipasi Masyarakat Terhadap Situ

\begin{tabular}{c|l|c|c}
\hline No. & \multicolumn{1}{|c|}{ Nama Situ } & $\begin{array}{c}\text { Jumlah } \\
\text { Respon } \\
\text { den }\end{array}$ & $\begin{array}{c}\text { Tingkat } \\
\text { Partisipasi } \\
\text { Secara Umum }\end{array}$ \\
\hline 1. & $\begin{array}{l}\text { Situ Rawa Gede / } \\
\text { Tirta Gede }\end{array}$ & 8 & Sedang \\
\hline 2. & Situ Pedongkelan & 8 & Sedang \\
\hline 3. & Situ Rawa Kalong & 8 & Sedang \\
\hline 4. & Situ Tipar & 8 & Rendah \\
\hline 5. & $\begin{array}{l}\text { Situ Jemblung / } \\
\text { Danau Situ Baru }\end{array}$ & 8 & Sedang \\
\hline 6. & Situ Gadog & 9 & Rendah \\
\hline \multicolumn{2}{r}{ Total Responden } & 49 & \\
\hline
\end{tabular}

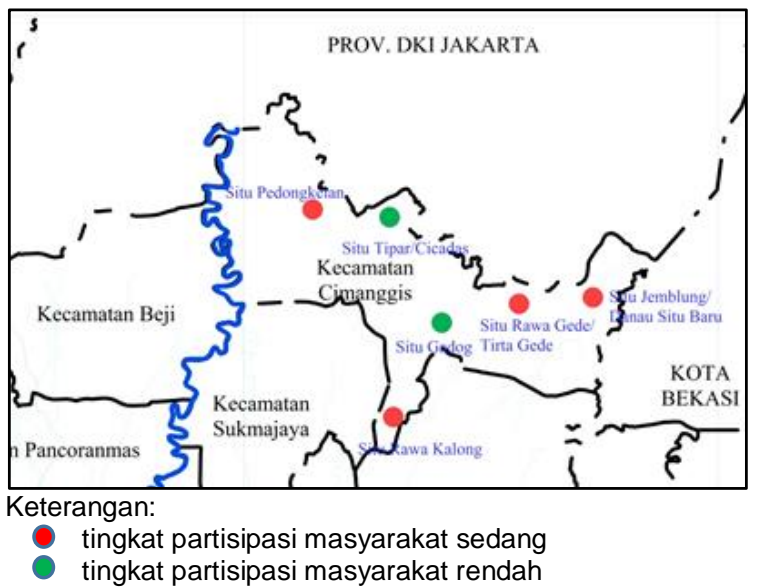

Gambar 2. Gambaran Tingkat Partisipasi pada Situ-Situ di Kecamatan Cimanggis

Berdasarkan gambar tersebut, warna merah menunjukkan tingkat partisipasi masyarakat terhadap pengurangan risiko kerusakan situ adalah sedang. Warna hijau menunjukkan tingkat partisipasi masyarakat terhadap pengurangan risiko kerusakan situ adalah rendah.

Gambaran umum hasil analisis data lapangan mengenai partisipasi masyarakat terhadap pengurangan risiko kerusakan 6 situ yang ada di Kecamatan Cimanggis. Partisipasi buah pikiran terhadap pengurangan risiko kerusakan situ dengan kategori rendah sebesar $32,6 \%$ atau sebanyak 16 orang, sedang sebesar $51 \%$ atau 25 orang dan tinggi sebesar $16,3 \%$ atau 8 orang. Partisipasi harta benda terhadap pengurangan risiko kerusakan situ dengan kategori rendah sebesar 48,9\% atau sebanyak 24 orang, sedang sebesar $40,8 \%$ atau 20 orang dan tinggi sebesar $10,2 \%$ atau 5 orang. Partisipasi tenaga terhadap pengurangan risiko kerusakan situ 
dengan kategori rendah sebesar $36,7 \%$ atau sebanyak 18 orang, sedang sebesar $48,9 \%$ atau 24 orang dan tinggi sebesar $14,2 \%$ atau 7 orang. Partisipasi keterampilan terhadap pengurangan risiko kerusakan situ dengan kategori rendah sebesar $61,2 \%$ atau sebanyak 30 orang, sedang sebesar $32,6 \%$ atau 16 orang dan tinggi sebesar $6,12 \%$ atau 3 orang. Partisipasi sosial terhadap pengurangan risiko kerusakan situ dengan kategori rendah sebesar $32,6 \%$ atau sebanyak 16 orang, sedang sebesar $53 \%$ atau 26 orang dan tinggi sebesar $14,2 \%$ atau 7 orang. Pengetahuan masyarakat tentang pengurangan risiko kerusakan situ dengan kategori rendah sebesar $20,4 \%$ atau sebanyak 10 orang, kategori pengurangan risiko kerusakan situ sedang sebesar $42,8 \%$ atau 21 orang dan pengurangan risiko kerusakan situ dengan kategori tinggi sebesar $36,7 \%$ atau 18 orang.

\subsubsection{Hasil Penelitian Tingkat Hubungan Partisipasi Masyarakat Terhadap Pengurangan Risiko Kerusakan Situ}

Jika nilai sig lebih kecil dari 0,05 $(0,000<$ $0,05)$ menunjukkan Ho ditolak dan Ha diterima maka disimpulkan terdapat korelasi yang signifikan.

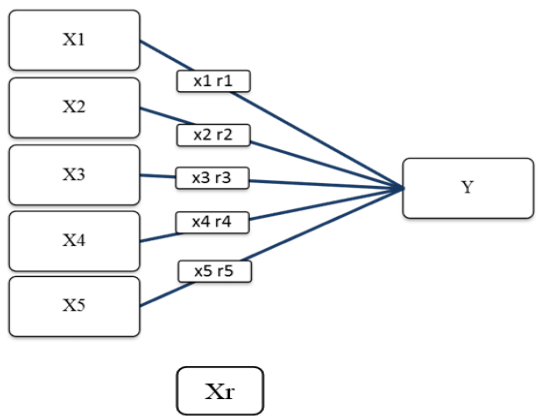

Gambar 3. Skema Hubungan Variabel $X$ Terhadap $Y$

Secara keseluruhan partisipasi masyarakat memiliki korelasi/hubungan yang signifikan terhadap pengurangan risiko kerusakan situ dengan total $r=1,271$. Hasil skema hubungan masing-masing variabel $X$ terhadap $Y$ seperti pada Gambar 3 adalah $r 1=0,170, \quad r 2=0,280, \quad r 3=0,273, \quad r 4=0,150$, $\mathrm{r} 5=0,398($ Tabel 5).
Tabel 5. Hasil Analisis SPSS Korelasi Spearman Rank Tingkat Partisipasi

\begin{tabular}{|c|c|c|}
\hline & & $\begin{array}{c}\text { Pelestarian } \\
\text { Situ }\end{array}$ \\
\hline \multirow{4}{*}{$\begin{array}{l}\text { Partisipasi } \\
\text { Buah Pikiran }\end{array}$} & Correlation & .170 \\
\hline & Coefficient & \\
\hline & Sig. (2-tailed) & .242 \\
\hline & $\mathrm{N}$ & 49 \\
\hline \multirow{4}{*}{$\begin{array}{l}\text { Partisipasi } \\
\text { Harta Benda }\end{array}$} & Correlation & .280 \\
\hline & Coefficient & \\
\hline & Sig. (2-tailed) & .051 \\
\hline & $\mathrm{N}$ & 49 \\
\hline \multirow{4}{*}{$\begin{array}{l}\text { Partisipasi } \\
\text { Tenaga }\end{array}$} & Correlation & .273 \\
\hline & Coefficient & \\
\hline & Sig. (2-tailed) & .058 \\
\hline & $\mathrm{N}$ & 49 \\
\hline \multirow{4}{*}{$\begin{array}{l}\text { Partisipasi } \\
\text { Keterampilan }\end{array}$} & Correlation & .150 \\
\hline & Coefficient & \\
\hline & Sig. (2-tailed) & .305 \\
\hline & $\mathrm{N}$ & 49 \\
\hline \multirow{4}{*}{$\begin{array}{l}\text { Partisipasi } \\
\text { Sosial }\end{array}$} & Correlation & $.398^{* *}$ \\
\hline & Coefficient & \\
\hline & Sig. (2-tailed) & .005 \\
\hline & $\mathrm{N}$ & 49 \\
\hline \multirow[t]{3}{*}{ Pelestarian Situ } & $\begin{array}{l}\text { Correlation } \\
\text { Coefficient }\end{array}$ & 1.000 \\
\hline & Sig. (2-tailed) & \\
\hline & $\mathrm{N}$ & 49 \\
\hline
\end{tabular}

**. Correlation is significant at the 0.01 level (2tailed)

*. Correlation is significant at the 0.05 level (2tailed)

Sumber: Hasil Analisis (2018)

Untuk mengetahui suatu nilai yang menyatakan besar hubungan dari variabel independen terhadap variabel dependen digunakan rumus koefisien determinasi, yaitu $K D=r^{2} \times 100 \%$ sehingga mendapatkan hasil seperti berikut, partisipasi bentuk buah pikiran memberikan kontribusi sebesar 2,89\%, partisipasi harta benda sebesar $7,84 \%$, partisipasi tenaga sebesar $7,45 \%$, partisipasi keterampilan sebesar 2,25\%, dan partisipasi sosial sebesar $15,84 \%$.

Nilai correlatian coefficeint $\mathrm{X} 1$ sebesar 0,170 berada di interval $0,100-0,233$ artinya partisipasi buah pikiran memiliki tingkat hubungan yang rendah. Nilai correlatian coefficeint $\mathrm{X} 2$ sebesar 0,280 berada di interval 0,234-0,367 artinya partisipasi harta benda memiliki tingkat hubungan yang sedang. Nilai correlatian coefficeint $X 3$ sebesar 0,273 berada di interval 0,234-0,367 artinya partisipasi tenaga memiliki tingkat hubungan yang sedang. Nilai correlatian coefficeint X4 sebesar 0,150 berada di interval 0,100-0,233 artinya partisipasi keterampilan memiliki 
tingkat hubungan yang rendah. Nilai correlatian coefficeint $\mathrm{X} 5$ sebesar 0,398 berada di interval $0,368-0,500$ artinya partisipasi sosial memiliki tingkat hubungan yang tinggi.

Dapat disimpulkan indikator partisipasi masyarakat terdapat hasil korelasi yang tinggi terhadap upaya pengurangan risiko kerusakan situ sebanyak 1 indikator, hasil korelasi yang sedang sebanyak 2 indikator dan rendah sebanyak 2 indikator. Tingkat korelasi yang tinggi yaitu partisipasi social, tingkat korelasi yang sedang diantaranya yaitu partisipasi harta benda dan tenaga sedangkan tingkat korelasi yang rendah yaitu partisipasi buah pikiran dan keterampilan.

Penelitian ini juga bertujuan untuk mengetahui upaya pemerintah untuk meningkatkan peran masyarakat dalam upaya pengurangan risiko kerusakan situ-situ di Kecamatan Cimanggis. Instansi pemerintah yang terkait dari segi pengurangan risiko kerusakan, konservasi, lingkungan hidup, maupun pariwisata adalah: BLH (Badan Lingkungan Hidup), Bimasda (Bina Marga dan Sumber Daya Air), dan Disporaparsenbud (Dinas Pemuda Olahraga Pariwisata Seni dan Budaya). Instansi-instansi tersebut sudah melakukan upaya semaksimal mungkin untuk melestarikan situ sesuai dengan cara bidangnya masing-masing, namun yang menjadi kendala ialah faktor biaya yang terbatas serta akses jalan sehingga sulit untuk melakukan perbaikan situ.

\subsubsection{Partisipasi Masyarakat Terhadap Pengurangan Risiko Kerusakan Situ Secara Khusus}

a. Tingkat Partisipasi Buah Pikiran atau Ide

Tingkat partisipasi buah pikiran atau ide yang dimiliki masyarakat Kecamatan Cimanggis tergolong rendah. Karakteristik masyarakat yang memiliki ijazah tertinggi berada pada lulusan SMA dan ljazah tertinggi kedua berada pada lulusan SMP dengan masing-masing sebesar $25 \%$ dan $20 \%$. Hal ini sejalan dengan pernyataan (Khikmawati, 1997) mengatakan bahwa mereka yang memiliki pendidikan yang lebih tinggi akan lebih tinggi derajat partisipasinya dalam pembangunan, hal mana karena dibawa oleh semakin kesadarannya terhadap pembangunan. Dengan ini dapat dilihat bahwa untuk mengeluarkan buah pikiran atau ide yang baik untuk pengurangan risiko kerusakan situ sangat terbatas karena tingkat pendidikan yang rendah. Partisipasi buah pikiran dapat diwujudkan pada berbagai kesempatan, seperti melalui pertemuan rapat $\mathrm{RT}$ atau rapat pokja (kelompok kerja) dengan memberikan ide atau gagasan untuk keberlangsungan situ ke depannya. Dapat juga berupa penyaluran ide-ide lewat lembaga yang ada di lingkungan sekitar. Mengembangkan program-program yang belum pernah dilakukan sebelumnya tentang pengurangan risiko kerusakan situ.

b. Partisipasi dalam Bentuk Harta Benda

Partisipasi dalam bentuk harta benda merupakan salah satu bagian yang paling penting terhadap pengurangan risiko kerusakan situ tetapi masih tergolong tidak cukup tinggi atau sedang. Adapun faktor yang menyebabkan sedangnya tingkat harta benda karena kebutuhan hidup mereka lebih tinggi jika dibandingkan dengan penghasilan yang mereka miliki. Penghasilan yang tidak mencukupi disebabkan karena status pekerjaan utama masyarakat Kecamatan Cimanggis yang paling dominan adalah bekerja sebagai buruh/karyawan/pegawai. Hal ini sejalan dengan pernyataan (Ross et al, 1967) bahwa hal ini tidak dapat dipisahkan satu sama lain karena pekerjaan seseorang akan menentukan berapa penghasilan yang akan diperolehnya. Pekerjaan dan penghasilan yang baik dan mencukupi kebutuhan sehari-hari dapat mendorong seseorang untuk berpartisipasi dalam kegiatan-kegiatan masyarakat. Pengertiannya bahwa untuk berpartisipasi dalam suatu kegiatan, harus didukung oleh suasana yang mapan perekonomian. Status pekerjaan juga dipengaruhi oleh pendidikan, semakin tinggi ijazah pendidikan maka akan semakin tinggi pula status pekerjaan atau jabatan maka penghasilan juga akan meningkat. Partisipasi harta benda dapat diwujudkan dengan cara memberikan bantuan sejumlah uang yang dititipkan pada uang kas RT atau uang kas pokja. Jika merasa keberatan untuk memberikan bantuan berupa uang, masyarakat dapat menggantinya dengan meminjamkan peralatan alat kebersihan miliknya saat melakukan kerja bakti pada lingkungan situ. Partisipasi harta benda juga bisa dilakukan dengan membuat poster, spanduk, leaflet dan sebagainya yang berisi ajakan atau perintah untuk pengurangan risiko kerusakan situ.

\section{c. Tingkat Partisipasi Tenaga}

Tingkat partisipasi tenaga yang dimiliki masyarakat Kecamatan Cimanggis tergolong sedang. Partisipasi dalam bentuk tenaga ini 
didominasi oleh laki-laki karena perempuan tidak cukup kuat untuk melakukan hal-hal berat sehingga perempuan hanya membantu menyumbangkan makanan dan minuman untuk warga yang sedang bergotong royong. Seperti pernyataan (Ross, 1967), bahwa pada dasarnya tempat perempuan adalah "di dapur" yang berarti bahwa dalam banyak masyarakat peranan perempuan yang terutama adalah mengurus rumah tangga, akan tetapi semakin lama nilai peran perempuan tersebut telah bergeser dengan adanya gerakan emansipasi dan pendidikan perempuan yang semakin baik. Partisipasi tenaga dapat diwujudkan dengan melaksanakan kegiatan kerja bakti seperti ikut membersihkan situ, mengikuti kegiatan penanaman pohon pada daerah sempadan situ. Sedangkan kegiatan untuk membuat/merenovasi tanggul situ dan pengerukan situ biasa dilakukan oleh PU Pusat yaitu BBWSCC (Balai Besar Wilayah Sungai Ciliwung Cisadane) yang dibantu oleh warga sekitar.

\section{d. Tingkat Partisipasi Keterampilan}

Tingkat partisipasi keterampilan yang dimiliki masyarakat tergolong rendah. Hal ini terbukti dari hasil responden yang mayoritas menjawab tidak pernah mengadakan pelatihan-pelatihan dalam rangka upaya pengurangan risiko kerusakan situ karena menurut warga yang biasanya melakukan pelatihan adalah dari pihak pemerintah, padahal tidak ada salahnya jika pengurus RW atau pengurus pokja mengadakan pelatihan kepada warganya yang lain agar seluruh masyarakat mengerti pentingnya menjaga kerusakan situ. Sejalan dengan pernyataan (Suryawan, 2004) pengetahuan dan keahlian. Dasar pengetahuan yang dimiliki akan mempengaruhi seluruh lingkungan dari masyarakat tersebut. hal ini membuat masyarakat memahami ataupun tidak terhadap tahap-tahap dan bentuk dari partisipasi yang ada. Partisipasi keterampilan dapat diwujudkan dengan cara memberikan pelatihan-pelatihan tentang pentingnya menjaga kelestarian situ, memberikan contoh yang baik dengan menjaga lingkungan situ, dan mengajak instansi lain atau komunitas untuk menjadi sponsor/donatur dalam kegiatan pengurangan risiko kerusakan situ.

e. Tingkat Partisipasi Sosial

Tingkat partisipasi sosial yang dimiliki masyarakat Kecamatan Cimanggis tergolong cukup tinggi. Karakteristik responden yang didominasi oleh penduduk berumur 50-54 tahun tahun sebanyak 13 orang dari 49 orang responden sehingga hal ini membuat tingkat partisipasi sosial tergolong tinggi karena masyarakat yang lebih tua pasti akan lebih dihargai di masyarakat sehingga akan lebih mudah untuk mengajak masyarakat dan mensugesti untuk ikut program pengurangan risko kerusakan situ-situ di Kecamatan Cimanggis. Sejalan dengan pernyataan Soelaiman (1980) Komunikasi yang intensif antara sesama warga masyarakat dengan pimpinannya serta antara sistem sosial di dalam masyarakat dengan sistem di luarnya. Partisipasi sosial dapat diwujudkan dengan cara menyebarkan informasi tentang adanya kegiatan pengurangan risiko kerusakan situ, mendiskusikan keberlanjutan situ antar sesama warga, berkoordinasi yang baik antar sesama warga sehingga tercipta kegiatan yang positif dan harmonis, seusai melakukan kerja bakti perlu diadakan evaluasi hasil kerja agar kedepannya semakin lebih baik (Dewanti, 2016; Dewanti et al, 2016).

\section{KESIMPULAN}

Dari hasil pembahasan di atas bisa disimpulkan sebagai berikut:

- Kontribusi partisipasi masyarakat dalam bentuk buah pikiran sebesar $2,89 \%$ dan keterampilan sebesar 2,25\% tergolong memiliki hubungan yang rendah. Dalam bentuk harta benda sebesar $7,84 \%$ dan tenaga sebesar $7,45 \%$ tergolong memiliki hubungan yang sedang. Sedangkan partisipasi masyarakat dalam bentuk sosial sebesar 15,84\% tergolong memiliki hubungan yang cukup tinggi.

- Tingkat partisipasi buah pikiran atau ide yang dimiliki masyarakat Kecamatan Cimanggis rendah, karena pendidikan ijazah tertinggi yang dimiliki masyarakat Kecamatan Cimanggis berada pada tingkat SMA dan SMP, sehingga dalam mengeluarkan buah pikiran atau ide untuk pengurangan risiko kerusakan situ sangat terbatas karena tingkat pendidikan yang rendah partisipasinya dalam pembangunan.

- Partisipasi dalam bentuk harta benda dalam pengurangan risiko kerusakan situ masih tergolong sedang, karena kebutuhan hidup mereka lebih tinggi jika dibandingkan dengan penghasilan yang mereka miliki.

- Tingkat partisipasi tenaga yang dimiliki masyarakat tergolong sedang. Partisipasi dalam bentuk tenaga ini didominasi oleh laki-laki karena perempuan tidak cukup kuat untuk melakukan hal-hal berat 
sehingga perempuan hanya membantu menyumbangkan makanan dan minuman untuk warga yang sedang bergotong royong.

- Tingkat partisipasi keterampilan yang dimiliki masyarakat tergolong rendah, karena tidak pernah dilakukan pelatihanpelatihan dalam rangka upaya pengurangan risiko kerusakan situ oleh mereka sendiri maupun instansi terkait. Tingkat keterampilan yang rendah karena tingkat pendidikan yang rendah sehingga masyarakat terbatas dalam mengembangkan kreatifitasnya untuk kemajuan situ.

- Tingkat partisipasi sosial yang dimiliki masyarakat Kecamatan Cimanggis tergolong cukup tinggi. Penduduk yang didominasi oleh umur 50-54 tahun tahun, membuat tingkat partisipasi sosial tergolong sedang karena masyarakat yang lebih tua pasti akan lebih dihargai di masyarakat sehingga akan lebih mudah untuk mengajak masyarakat dan meyakinkannya untuk ikut program pengurangan risiko kerusakan situ-situ di Kecamatan Cimanggis.

\section{DAFTAR PUSTAKA}

Akhirianto, N.A. dan H.S. Naryanto. 2016. Kajian Kapasitas dan Persepsi Masyarakat Pangalengan terhadap Bencana Tanah Longsor. JRKI 2(2): 117126.

Arikunto, S. 2006. Prosedur Penelitian Suatu Pendekatan Praktik. Rineka Cipta. Yogyakarta.

BPS Kota Depok. 2015. Depok Dalam Angka.

Dewanti, T. Y., D. Sugandi dan B. Waluya. 2016. Partisipasi Masyarakat Dalam Upaya Pelestarian Situ-Situ di Kota Depok. Antologi Geografi, 4(2).

Dewanti, T. Y. 2016. Partisipasi Masyarakat Dalam Upaya Pelestarian Situ-Situ di Kota Depok. Skripsi. FPIPS UPI.

Feldt, L and R.L. Brennan. 1989. Reliability. Dalam Robert L. Linn (Eds). Education
Measurement ( $\left.3^{\text {rd }} \mathrm{Ed}\right)$, American Council on Education: 105-143. New York.

Khikmawati, M. 1997. Partisipasi Orang Tua Murid Melalui BP3 dalam Membantu Penyelenggaraan Pendidikan Di STM Pembangunan, Yogyakarta. Makalah Komprehensif. FIP UNY.

Naryanto, H.S. 2011. Analisis Risiko Bencana Kemungkinan Meluapnya Air atau Jebolnya Tanggul Situ Bojongsari, Kota Depok. Jurnal alami 16(2): 24-33.

Naryanto, H.S. 2013. Kajian Penilaian Risiko Bencana Kemungkinan Jebolnya Tanggul Waduk Penjalin, Kabupaten Brebes, Provinsi Jawa Tengah. Jurnal Sains dan Teknologi Indonesia 15(1): 24-33.

Nazir, M. 1983. Metode Penelitian. Ghalia Indonesia. Bogor.

Pabundu, T. 1997. Metode Penelitian Geografi. Gramedia. Jakarta.

Pemerintah Kota Depok. 2012. Peraturan Daerah Rencana Tata Ruang Wilayah Kota Depok Tahun 2012-2032.

Puspita, L., E. Ratnawati, I.N.N Suryadiputra dan A.A. Meutia. 2005. Lahan Basah Buatan di Indonesia, Wetlands International Indonesia Programe, Ditjen PHKA. Bogor. 261p.

Ross, M.G., and B.W. Lappin. 1967. Community Organization: Theory, Principles And Practice. Second Edition. Harper \& Row Publishers. New York.

Satori dan Komariah. 2014. Metodologi Penelitian Kualitatif. Alfabeta. Bandung.

Soelaiman, H. 1980. Partisipasi Sosial dalam Usaha Kesejahteraan Sosial. Bandung.

Sugiyono. 2010. Metode Penelitian Pendidikan. Alfabeta. Bandung.

Sugiyono. 2013. Statistika Untuk Penelitian, Alfabeta. Bandung.

Suharto, E. 2004. Kebijakan Sosial sebagai Kebijakan Publik. Alfabeta. Bandung.

Suryawan, A.A. 2004. Studi Partisipasi Masyarakat dalam Pelestarian dan Pengembangan Kawasan Alun-Alun Surakarta. Program Sarjana Jurusan Teknik Perencanaan Wilayah dan Kota, Universitas Diponegoro Semarang. 